\title{
THE IMPLEMENTATION OF INTEGRATED LEARNING FOR DEVELOPING THE ENTREPRENEURSHIP READINESS FOR THE STUDENTS OF VOCATIONAL HIGH SCHOOL MAJORING IN ARCHITECTURE ENGINEERING
}

\author{
V. Lilik Hariyanto \\ lilik_hariyanto@uny.ac.id \\ Faculty of Engineering, Universitas Negeri Yogyakarta \\ Husaini Usman \\ husaini_usman@uny.ac.id \\ Faculty of Engineering, Universitas Negeri Yogyakarta \\ Pardjono \\ pardjono@uny.ac.id \\ Faculty of Engineering, Universitas Negeri Yogyakarta
}

\begin{abstract}
The objective of the research was to: (1) find the level of integrated learning effectiveness between the entrepreneurship subjects and the stone and concrete practical subject from the perspective of the teachers and the students; (2) to find the level of integrated learning implementation between the entrepreneurship subject and the stone and concrete practical subject; (3) to find the level of teacher and student activities within the integrated learning between the entrepreneurship subject and the stone and concrete practical subject; and (4) to find the level of student readiness within the integrated learning between the entrepreneurship subject and the stone and concrete practical subject. The researchers implemented the Research and Development approach with an orientation toward the product development. The research period in the form of learning implementation within the classroom was from January to February 2013. The research site was in 2 Pengasih State Vocational High School Kulonprogo. The research subjects were the students of XI Grade Stone and Concrete Construction Engineering, 2 Pengasih State Vocational High School, Kulonprogo. The research procedures were divided into two stages namely: (1) pre-integrated learning implementation; and (2) integrated learning implementation. The research data included: (1) the effectiveness of integrated learning from the perspective of the teachers and the students; (2) the implementation of integrated learning; (3) the level of activeness that the teachers and the students exposed; and (4) the readiness of the students for performing entrepreneurship based on the achievement of learning competences in the domain of knowledge, attitude and skill. The data analysis was performed in a descriptive-qualitative manner by providing logical narratives according to the research objectives. The results of the research were as follows: (1) the implementation of integrated learning, from the perspective of both the teachers and the students, had been in the category of effective to very effective; (2) the implementation of integrated learning had been in the category of good to very good; (3) the teachers and the students had been in the category of active to very active; and (4) the students had been in the category of ready for performing the entrepreneurship with the achievement of learning scores for more than the already determined passing grade.
\end{abstract}

Keyword: integrated learning, Vocational high school students' entrepreneurial readiness 


\section{INTRODUCTION}

The development of entrepreneurship readiness for the learning participants in Indonesia by means of educational world had been an urgent needs; meanwhile, the embryo of independent entrepreneurship as a side job for the learning participants had been widely spread in many regions. There had been many students and university students who would like to start a new business although their business was a small-scale one. in addition, the entrepreneurship seminars increasingly held anywhere also encouraged the atmosphere of independent entrepreneurship efforts. Interestingly, educational institutions the learning participants' center of training started to pay attention to the appearing spirit of entrepreneurship among their students; these institutions started to encourage the entrepreneurship spirit among their students. One of the potential site that should be encouraged was the school/the campus. There had been countless human resources educated and graduated from the site but not all of them were lucky. Honestly, most of graduates still had orientation toward the job-searching activities. There were very few graduates who had strong willingness to start a business and to open a new worksite (Khasali, 2010). Moreover, the efforts of encouraging the independent entrepreneurship itself were not apart of the government programs in encouraging both the local and the national economic growth. Ideally, the number of independent entrepreneurship in minimum should be $2 \%$ of the total population. On the other hand, until 2009 the percentage of independent entrepreneurship was below $0.18 \%$; in other words, the percentage of independent entrepreneurship was still below the ideal proportion. The unideal proportion, certainly, encouraged the government altogether with the private institutions to implement the programs of creative industry.

From the educational institutions themselves, the entrepreneurship program for the students had been improved continuously. The government had issued the Instruction of the President of Republic Indonesia Number 4 Year 1995 (Presiden Republik Indonesia, 1995) regarding the "national movement of socializing and empowering entrepreneurship." Then, the presidential instruction was followed up by the Department of National Education (now the Ministry of National Education) through the launching of entrepreneurship development programs in the form of educational and activity packages for the students of vocational high school and the university students. The government through the Department of Cooperation and Small-andModerate Scale Business had also launched the "Getuk Nasional" (Gerakan Tunas Kewirausahaan Nasional or the Movement of National Entrepreneurship Pioneer) program for the students of Senior High School and the university students. The program was the deliverance of entrepreneurship spirit in an early period for the students in specific and the beginners in general who would start a new entrepreneurship effort (Ali in Murtini, 2009 , p. 7), and was the form of the government's attention toward the high rate of unemployment in the educated people especially in the senior high school and university graduates.

The situation was caused by the fact that the implementation of the syllabus in the productive subjects and the entrepreneurial subjects in the Vocational High School had been implemented separately whereas the characteristics of both subjects were very similar and both of the subjects might be integrated in the learning aspects within the domain of knowledge, attitude and skill in an actual manner.

On the other hand, the learning participants' success in the learning process was not determined by the cleverness that they possessed; instead, their success was determined by the other factors. The level of cleverness only contributed $20 \%-30 \%$ of their success in the learning process; the rest of the portion was determined by the soft skills (Santoso, 2009). Soft skills were the a group of attitudes and capabilities that one demanded in order to be effective in performing the job and improving himself or herself (Leung, 2008, p. 1).

The development of entrepreneurship ability in the learning participants would be optimal if the soft skills would be included within the process of the development. Soft skills were the key to the success and, in this case, the soft skills included leadership, decision taking, conflict resolution, communication, creativity and presentation capability 
(Kaipa \& Milus, 2005, pp. 5-6). Thereby, the graduate candidates would have sufficient capability so that they would not be confused when they had to enter the market as the actors of entrepreneurship efforts.

The graduates of Vocational High School had opportunities for the entrepreneurship efforts; unfortunately, they had not found these opportunities because they had not been prepared to the entrepreneurs. Therefore, the students should be aware that "the graduates who had the capability of job seacrhing should move to the domain of job-field creating."

In the research, the integrated learning that the researchers referred to was a collaborative learning between the Entrepreneurship Subject and the Productive Subject of Stone and Concrete Construction for the students of Vocational High School majoring in Architecture Engineering. Then, the entrepreneurship readiness was the achievement of learning process that included: (1) the knowledge competence in the domain of productive practice; (2) the knowledge competence in the domain of entrepreneurship; (3) the attitude competence; and (4) the practicality competence in the domain of productive practice.

There had been multiple ways to implement the integration of entrepreneurial education in the vocational high schools. The Ministry of National Education (2010) proposed that the process of integration within the entrepreneurial education should not be implemented by creating new curriculum; instead, the entrepreneurial education might be included to the components of the curriculum.

There had been many entrepreneurial values that might be embedded to the students in all subjects contained within the curriculum. However, not all of the subjects should embed the entrepreneurial values to the students especially the ones that had similar intensity because the embedding would be a heavy burden for the students, the teachers, the schools and the related elements. Therefore, the embedding of entrepreneurial values should be given to the subjects that had similar characteristics to the objectives of the entrepreneurial values embedding to the students. The embedding should be done stage by stage by selecting a number of main values as the starting for the embedding of the other entrepreneurial values. Then, the main entrepreneurial values would be integrated to one of the related subjects. The subjects that had been the target of the integration should focus only on the embedding of certain entrepreneurial values that were similar to the characteristics of the related subjects. According to the Ministry of National Education (2010, pp. 58-59), the main entrepreneurial values that might be integrated were as follows: (1) independent; (2) creative; (3) risk-taking; (4) leadership; (5) action-oriented; and (6) hardworking.

The integrated learning enabled the students to be involved directly; furthermore, the teachers might motivate the students to achieve the learning objectives optimally and might stimulate the students to find the development of the learning materials in order to be studied for the next meeting. Thereby, the integrated learning emphasized on the mastery of soft skills and on the mastery of hard skills within unity of curriculum. Drake (2007, p. 27) stated that the integrated curriculum was intended to create a curriculum that should be in accordance with the learning demand. The integration-based curriculum was intended to form the term know, do and be (Drake, 2007, p. 7). The term know had an orientation to the big idea and the big understanding, the term do had an orientation to the big skills, the term be had an orientation to the attitude, belief and behavior building. The relation between the three terms (know, do and be) and the integrated learning was that the element of know, do and be might be achieved synergically.

The universal concept of an integrated curriculum was a learning proposition in the framework of the term big idea. The statement also showed the high degree of learning proposition in the framework of the term know. On the other hand, the learning essence that might be generalized was an understanding in the framework of the term big understanding. The concept also implied that the learning understanding might be preserved continuously as a results of the learning process that had passed. The general skills that the students learned were a group of big skills. Such situation described that teaching was one of the activities that formed the students' capabilities from the ongoing learn- 
ing process. As a result, the term do had always been related to the term know.

The learning achievements in the aspect of values was identified as a part of the term be. If the teacher would like to put the term be in the students, then he or she would implement the value as the curriculum guideline. If the teachers who would like to put the values in the students, then they should continuously strengthen the students knowledge by means of learning process that put a high priority on the aspect of behavioral values.

There were two approaches for integrating the elements of a subject from a curriculum into a school of discipline, namely: (1) Connected model; and (2) Nested model.

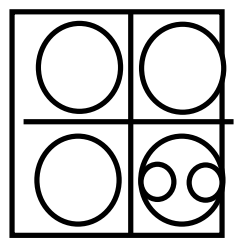

Connected Model

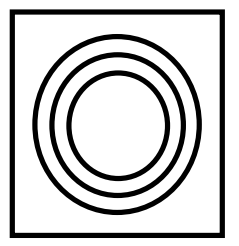

Nested model model

Figure 1. The Integration Model of the Subject to the Curriculum

The connected model was an integration approach that emphasized the elements of interconnectedness from each of the subjects and the teaching materials such as the interconnection from one topic to another, the interconnection from one concept to another, the interconnection from one skills to another and the interconnection from the subjects to the job field in the present time and in the future. Several advantages that the first model had were as follows: (1) the students attained understanding form a comprehensive learning; and (2) the students had a process of value internalization and of meaningful learning. On the other hand, the weakness that the first model had was that not all of the integrations in the schools of many disciplines might be form by the implementation of the model.

On the other hand, the nested model was an integration approach that had an orientation on the achievement of multiple skills in each of the subject matters as well as the multiple targets on the learning achievements. The development of the model em- pashized on the design by involving the combination of the elements that might not be forced and the element combinations would lead to the easiness for the students in accomplishing their learning tasks. Several advantages that the nested model had were as follows: (1) the learning experience was formed by means of achievement of the opportunity that had been set; (2) the variation of the students' learning achievements became wider and various; (3) the teachers individually might develop the integration materials according to the students' needs; and (4) the approach was very suitable for the teachers in terms of developing the students' thinking capabilty and the students' collaboration in the learning process because the learning activities were implemented without any force. On the contrary, the weaknesses of the approach were as follows: (1) the students were frequently confused because they had to achieve multiple targets; and (2) the scales of priority that the students should achieve became unclear and not focused.

Based on the two approaches, namely the connected model and the nested model with the strengths or the advantages and the weaknesses, the development of integrated entrepreneurship learning in order to build the students' readiness in performing the entrepreneurship would be very suitable by means of the combination of both approaches. The reason was that the connected model might form the integrated entrepreneurship learning in the productive domain and the learning process in the productive domain would be more meaningful by means of the strengthening in the hard skills. The emphasize of the interconnectedness in the model was found between the formation of the students' entrepreneurial readiness and the hard skills that the students possessed in the each topic, concept, skill and job field in the present time and in the future.

Readiness was a psychological condition in which an individual had been ready to perform a reaction as an impact of an action. In the Dictionary of Education compiled by Good (1973), he provided a limitation as follows: "Readiness: willingness, desire and ability to engage in a given activity, depending on the learner's level of maturity, previous experience, and mental and emotional set." The limitation might be defined as a willing- 
ness that appeared within one's self altogether with the desire and the wish within an effort to pursuit certain activities. Such encouragement was personal and dependent on the level of maturity, past experience, mental condition and learner emotion.

Meanwhile, the maturity formed the character and the strength in one's self to perform a reaction with certain manners (Soemanto, 2003, pp. 192-197). The meaning was that an individual's maturity was personal strength and charactertistics and the maturity enabled the individual to adapt himself or herself to the environment and to solve the problems that he or she encountered. The readiness of one's maturity development was heavily demanded in each learning process that an individual experienced.

Thorndike (Hilgard \& Bower, 1975, p. 32) stated that man's learning if fundamentally the action of the laws of readiness exercise, and effect. The definition implied that the fundamental behavior within a learning process that a human experienced should fulfill the law of preparation, training and impact. Hilgard \& Bower (1975, p. 33) argued that the satisfaction as well as the failure was dependent on the individual's readiness in accepting or in denying the incoming responses. In this case, the readiness tended to be defined more as a form of selfpreparation in order to accept orto deny something (reinforcement) that had been learned including the individual's ability to put himself or herself in relation to the physical and the mental readiness.

Regarding the term entrepreneurship, the term entrepreneurship in bahasa Indonesia would be translated as wirausaha. The term wirausaha was derived from two words namely wira, meaning a brave person that could be made as a main role model, and usaha, meaning a hardwork in order to attain or to generate something. As a result, the researchers might conclude that wirausaha or entrepreneurship was an person or an individual that had creativity and high enthusiasm in working and in achieving the success in his or her business.

According to Princes (2004, p. 11), entrepreneurs referred to the people who always worked hard and who were creative in searching for the business opportunities, in taking on the existing opportunities and in manipulating the creation of alternative opportunities as new opportunities with the factors of competitive edge. Say (Princes, 2004, p. 76) defined the entrepreneurs as,"a person who shifts economic resources outs of an area of lower productivity into an area of higher productivity and higher yield." In other words, these people changed the economic sources with low productivity into theones with high productivity. In addition, Zimmerer \& Scarborough (2008, p. 5) proposed the definition of entrepreneurs as follows: an entrepreneur is one who creates a new business in the face of risk and uncertainty for the purpose of achieving profit and growth by identifying opportunities and assembling the necessary resources to capitalize on those opportunities.

The definition was that an entrepreneur was a person who create a new business opportunity by overcoming the risk and the uncertainty with an objective of earning profit and development by means of identifying the opportunities through the necessary resources in order to gain the benefit (the opportunity). The understanding was that the main role of an entrepreneur in making changes was not on how to do something better but, instead was on how to something differently. In other words, an entrepreneur was an innovator and a creator who dared to take risks by calculating the existing opportunities.

On the other hand, the definition of entrepreneurship was an activity of organizing multiple production factors that had been led by an entrepreneur in order to be a profitable economic activities as a form of his or her return upon the risk-taking. The definition had been based on a statement by Suryana (2006, p. 14) which stated that, "entrepreneurship is the result of a disciplined, systematic process of applying creativity and innovation to solve the problems and to exploit opportinuties that people face everyday." The statement implied that entrepreneurship was a result of discipline and of a process of applying creativity and innovation systematically in order to benefit and to resolve the problems that had been encountered everyday. According to the Appendix of the Presidential Instruction of Republic Indonesia Number 4 Year 1995 on June $30^{\text {th }}, 1995$ (Presiden Republik Indonesia, 1995): Entrepreneurship was the enthusiasm, the attitude, the behavior and the capability of 
an individual in handling a business or an activity that led to the efforts of searching for, creating and implementing the job procedures, the technology and the product by improving the efficiency in order to provide a better service or in order to gain a bigger profit.

The Relationship between the Definition of Entrepreneurship and the Students' Readiness in Implementing the Entrepreneurial Efforts. The maturity that the students of vocational high schools possessed, then, would develop the mental capacity and would influence the learning activity as well as the readiness to enter job field after having been graduated. According to Finch \& Crunkilton (1999, p. 75), "the mayor goal vocational instruction is to prepare students for successful employment in the labor market;" the statement implied that the educational objective in the vocational high schools was to prepare the students to be succesful workers in the job field. Therefore, the graduates of vocational high schools were expected to be able and to be ready as successful workers in the employment both as employees or as entrepreneurs. The students of vocational high schools who had achieved maturity, namely the ones who had been 17-18 years old, had been ready to go to work and to perform te entrepreneurial efforts be-cause during their adolescent period they had been preparing themselves to join the employ-ment and one of the preparations included to be the entrepreneurs. In addition, the re-searchers found that people who were around 16-19 years old had been justified to perform their jobs; they had already had readiness both physically and psychologically for performing their jobs.

The entrepreneurship readiness, in relation to the students of vocational high schools as the entrepreneurial candidates, was very closed to the educational hierarchy in terms of selecting the appropriate values that should be embedded in the entrepreneurial education. Several reasons that should be considered crefully. Matthoriq, Triwastuti, \& Hidayah (2009) stated that vocational high schools had an irreplacable role in creating the atmosphere of entrepreneurship. The reason was that: (1) vocational high schools were the educational level that might be reached by most of the people with multiple economic background; (2) vocational high schools were a formal educational institution that had been develop- ed in order to generate the ready-to-work generations and, thereby, the students and/or the graduates were perceived to be ready to work in the moderate level of employment or to be the staffs with moderate capability (pelaksana madya) who had technical skills and capabilities as well as a thinker; and (3) the Government by means of the Directory of Vocational High School Coaching had already committed to develop the entrepreneurial training and education for the students of vocational high schools throughout Indonesia.

The importance of entrepreneurial education for the students of vocational high schools had actually been realized by many parties. In fact, in several regions there had been vocational high schools that put on the label of entrepreneurship and that proclaimed the entrepreneurial enthusiasm as the main part of learning process altogethere in the same time. In addition, these vocational high schools also included the entrepreneurial subjects in the curriculum. However, the entrepreneurial subjects seemed to be normative and only paid attention to two aspects namely the attitude and the skils. The normative entrepreneurial subjects of course made the students to be less responsive and less tough in overcoming the problems that relatively new. As a result, the students tended to pursuit the high values but they had poor understanding toward the substances of the entrepreneurial subjects. Therefore, there should be a new concept of entrepreneurial education that paid attention to the three educational aspects namely knowledge, attitude and skill altogether with the education of hard skills and soft skills.

Based on the statements, the term readiness in the research might be defined equally to that of the term capability. On the other hand, capability was viewed as a part of elements within the three domains namely the cognitive, the affective and the psychomotoric domains Edward, (1982). The opinion was in accordance with the educational system in Indonesia that regarded the learning participants as a complete individual. Thereby, people had already understood the importance of knowledge, skills, attitudes and values both for the students as the labor candidate and for the graduates that had been working. In accordance with the educational objectives that had been explained previously, the entrepreneurial 
readiness in the research was as equally as the capability for the job equipment. A student might be said as an entrepreneur if he or she had already had capabilities that included certain aspects of knowledge, skills and attitudes according to his or her domain of skills.

The ability might be measured by means of assessment activities that were conducted in the classroom. The assessment was a form teacher activities in relation to the decision making about the competence achievements or the learning results of the learning participants who attended certain learning process. Therefore, there should be necessary data as the reliable information that would be made as the foundation in the decision-making process. In this case, the decision was related to the success or the failure of the learning students in achieving a competence.

Recalling the knowledge, the skills, the attitudes and the values that the students had basically attained in the learning process, the entrepreneurial readiness in the research was related to the learning results of the students in the cognitive, affective and psychomotoric domains. On the other hand, the learning objectives of vocational education was closely related to the business domain; therefore, such dynamic had been in accordance with the theory proposed by Thorndike, saying that the learning results might be transferred if the learning experiences in the schools contained the elements that were identical to those of the problems in the daily life within the community (Mappa, Achsin, \& La Sulo, 1984).

Some of the research problems would be formulated by the researchers as follows: (1) how significant was the level of integrated learning effectiveness in developing the entrepreneurial readiness of the vocational high school students from the teachers' perspective? (2) how significant was the level of integrated learning effectiveness in developing the entrepreneurial readiness of the vocational high school students from the teachers' perspective? (3) how significant was the level of integrated learning implementation in developing the entrepreneurship readiness of the vocational high school students? (4) how significant was the level of teachers' activeness in developing the entrepreneurship readiness of the vocational high school students? (5) how significant was the level of students' activeness in developing the entre- preneurship readiness of the vocational high school students? (6) how significant was the level of entrepreneurship readiness in the students of vocational high schools?

The objectives of the research was: (1) to find the level of integrated learning effectiveness between the entrepreneurial subjects and the practical subjects of stone and concrete construction; (2) to find the level of integrated learning effectiveness between the entrepreneurial subjects and the practical subjects of stone and concrete construction; (3) to find the level of teachers' and students' activeness toward the implementation of integrated learning between the entrepreneurial subjects and the practical subjects of stone and concrete construction; and (4) to find the level of students' entrepreneurial readiness within the context of vocational high schools in the integrated learning process between the entrepreneurial subjects and the practical subjects of stone and concrete construction.

The advantages of the research were as follows: (1) theoretically, the research was expected to provide contribution in the form of review on the integrated learning between the entrepreneurial subjects and the practical subjects of stone and concrete construction in order to develop the entrepreneurial readiness within the students of Vocational High Schools majoring in the Stone and Concrete Construction Engineering Study Program; and (2) practically, the research was expected to be implemented in the learning process and to give suggestions to: (a) the teachers in order to develop better learning culture and enthusiasm, (b) the students in order to develop better learning culture and enthusiasm so that they would be encouraged to benefit the available learning facilities in order to gain more learning experiences in combining the knowledge, the skills and the attitudes under the actual demands in the business domain, (c) the vocational high schools in order to be made as the guidelines in the learning implementation that had orientation toward the students' readiness in performing the entrepreneurial efforts and (d) to the business domain in order to assist the preparation of young, reliable and well-qualified entrepreneurs so that these entrepreneurs might contribute something to the improvement of the family, the nation and the country economic background. 


\section{RESEARCH METHOD}

The researcher implemented the research and development approach in performing the investigation within the research and the approach had an orientation toward the product development. Borg \& Gall (1989) stated the research and development approach would generate certain products. In the research, the product would be the integrated learning process that might be implemented in the vocational high schools.

The research period was January 2013 - February 2013 and, during the period, the researchers observed the implementation of integrated learning in the class. Then, the research site was 2 Pengasih Kulonprogo State Vocational High School.

The research targets/subjects were the students of Grade XI Stone and Concrete Construction Engineering 2 Pengasih Kulonprogo State Vocational High School.

The research procedures were divided into two stages as follows: (1) the pre-learning implementation stage that included: (a) the preparation of research instruments that had been validated; (b) the perception establishment toward the materials of integrated learning among the teachers and the related elements; and (c) the preparation of learning facilities; (2) the learning implementation stage that included: (a) the entrepreneurial learning; (b) the practical learning of stone and concrete construction engineering; and (c) the evaluation.

The research data covered: (1) the effectiveness of integrated learning from the perspective of the teachers and the students that was measured based on the following indicators: (a) accuracy, (b) stability, (c) objectivity, (d) practicality and (e) language use; (2) the implementation of integrated learning that was measured based on the following indicators: (a) general implementation, (b) planning and objective, (c) interaction, (d) learning materials, (e) reading materials, (f) assignments, (g) assessment/evaluation, (h) teachers and (i) language use; (3) the level of teachers' activeness that was measured based on the following indicators: (a) introduction, (b) main activities, (c) conclusion and (d) language use; (4) the level of students' active- ness that was measured based on the following indicators: (a) concentration during the learning process, (b) note-taking, (c) asking questions, (d) answering questions (from the teachers), (e) proposing opinions and (f) language use; and (5) the level of students' entrepreneurial readiness that was measured based on the competence achievements in the domain of knowledge, skills and attitudes.

Within the research, the data analysis was performed in a descriptive-qualitative manner by providing logical narratives according to the research objectives. In addition, the data that had been gathered by means of research instruments then would be analyzed qualitatively and quantitatively.

\section{RESULTS AND DISCUSSIONS}

The effectiveness of integrated learning from the perspective of the teachers was investigated within the data gathering process and the researchers selected three teachers, consisting of two productive teachers and one entrepreneurial teachers, to be the respondents. The data gathering process was performed by implementing the assessment instruments and the instruments were distributed in each meeting. In total, there were four occasions where the researchers distributed the instruments with the following arrangement: (1) at the end of the third meeting; (2) at the end of the seventh meeting; (3) at the end of the tenth meeting; and (4) at the end of the thirteenth meeting. From the results of the analysis, the researchers drew the conclusions in the following tables.

The level of integrated learning effectiveness from the perspective of the students was measured by the students themselves. The researchers selected four students to be the assessors randomly and these students were the members of the learning groups in the schools. The aspects that the students observed were directed to the statement items that had been developed from the indicators that had been planned. The measurement was performed in the teaching-learning activities for four occasions namely: (1) at the end of the third meeting; (2) at the end of the seventh meeting; (3) at the end of the tenth meeting; and (4) at the end of the thirteenth meeting. 
Tabel 1. The Assessment Results on the Integrated Learning Effectiveness from the Perspective of the Teachers

\begin{tabular}{|c|c|c|c|c|c|c|c|c|c|}
\hline \multirow{3}{*}{ No } & \multirow{3}{*}{$\begin{array}{l}\text { Aspect of } \\
\text { Assessment }\end{array}$} & \multicolumn{8}{|c|}{ Results of Assessment } \\
\hline & & \multicolumn{2}{|c|}{$\begin{array}{l}\text { At the end of the } 3^{\text {rd }} \\
\text { meeting }\end{array}$} & \multicolumn{2}{|c|}{$\begin{array}{l}\text { At the end of the } 7^{\text {th }} \\
\text { meeting }\end{array}$} & \multicolumn{2}{|c|}{$\begin{array}{l}\text { At the end of the } \\
10^{\text {th }} \text { meeting }\end{array}$} & \multicolumn{2}{|c|}{$\begin{array}{l}\text { At the end of the } \\
13^{\text {th }} \text { meeting }\end{array}$} \\
\hline & & Mean & Criteria & Mean & Criteria & Mean & Criteria & Mean & Kriteria \\
\hline 1 & Overall & 69,00 & $\begin{array}{c}\text { Very } \\
\text { effective }\end{array}$ & 76,50 & $\begin{array}{c}\text { Very } \\
\text { effective }\end{array}$ & 78,00 & $\begin{array}{c}\text { Very } \\
\text { effective }\end{array}$ & 78,50 & $\begin{array}{c}\text { Very } \\
\text { effective }\end{array}$ \\
\hline 2 & Appropriateness & 17,50 & $\begin{array}{c}\text { Very } \\
\text { appropriate }\end{array}$ & 18,50 & $\begin{array}{c}\text { Very } \\
\text { appropriate }\end{array}$ & 19,50 & $\begin{array}{c}\text { Very } \\
\text { appropriate }\end{array}$ & 20,00 & $\begin{array}{c}\text { Very } \\
\text { appropriate }\end{array}$ \\
\hline 3 & Continuity & 12,00 & $\begin{array}{l}\text { Very } \\
\text { continuous }\end{array}$ & 14,00 & $\begin{array}{l}\text { Very } \\
\text { continuous }\end{array}$ & 13,50 & $\begin{array}{c}\text { Very } \\
\text { continuous }\end{array}$ & 13,00 & $\begin{array}{c}\text { Very } \\
\text { continuous }\end{array}$ \\
\hline 4 & Objectivity & 13,50 & $\begin{array}{c}\text { Very } \\
\text { objective }\end{array}$ & 13,50 & $\begin{array}{c}\text { Very } \\
\text { objective }\end{array}$ & 14,50 & $\begin{array}{c}\text { Very } \\
\text { objective }\end{array}$ & 14,50 & $\begin{array}{c}\text { Very } \\
\text { objective }\end{array}$ \\
\hline 5 & Practicality & 14,50 & Practical & 17,50 & Practical & 17,00 & Practical & 17,00 & Practical \\
\hline 6 & Language Use & 11,50 & Very good & 13,00 & Very good & 13,50 & Very good & 14,00 & Very good \\
\hline
\end{tabular}

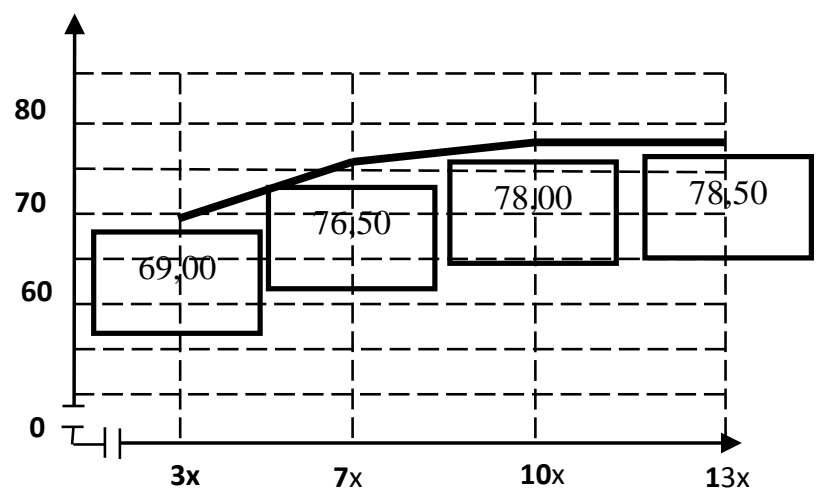

Figure 2. The Diagram of Assessment Results on the Integrated Learning Effectiveness from the Perspective of the Teachers

Tabel 2. The Assessment Results on the Integrated Learning Effectiveness from the Perspective of the Students

\begin{tabular}{|c|c|c|c|c|c|c|c|c|c|}
\hline \multirow{3}{*}{ No } & \multirow{3}{*}{$\begin{array}{l}\text { Aspects of } \\
\text { Measurement }\end{array}$} & \multicolumn{8}{|c|}{ Note } \\
\hline & & \multicolumn{2}{|c|}{$\begin{array}{l}\text { At the end of the } \\
3^{\text {rd }} \text { meeting }\end{array}$} & \multicolumn{2}{|c|}{$\begin{array}{l}\text { At the end of the } 7^{\text {th }} \\
\text { meeting }\end{array}$} & \multicolumn{2}{|c|}{$\begin{array}{l}\text { At the end of the } \\
10^{\text {th }} \text { meeting }\end{array}$} & \multicolumn{2}{|c|}{$\begin{array}{l}\text { At the end of the } \\
13^{\text {th }} \text { meeting }\end{array}$} \\
\hline & & Mean & Criteria & Mean & Criteria & Mean & Criteria & Mean & Kriteria \\
\hline 1 & Overall & 72,00 & Effective & 74,80 & $\begin{array}{c}\text { Very } \\
\text { effective }\end{array}$ & 76,80 & $\begin{array}{c}\text { Very } \\
\text { effective }\end{array}$ & 77,30 & $\begin{array}{c}\text { Very } \\
\text { effective }\end{array}$ \\
\hline 2 & Appropriateness & 18,25 & Appropriate & 20,00 & $\begin{array}{c}\text { Very } \\
\text { appropriate }\end{array}$ & 20,50 & $\begin{array}{c}\text { Very } \\
\text { appropriate }\end{array}$ & 20,75 & $\begin{array}{c}\text { Very } \\
\text { appropriate }\end{array}$ \\
\hline 3 & Continuity & 12,50 & Continuous & 12,75 & Continuous & 13,50 & $\begin{array}{c}\text { Very } \\
\text { continuous }\end{array}$ & 13,25 & $\begin{array}{c}\text { Very } \\
\text { continuous }\end{array}$ \\
\hline 4 & Objectivity & 13,00 & $\begin{array}{c}\text { Very } \\
\text { objective }\end{array}$ & 13,25 & $\begin{array}{c}\text { Very } \\
\text { objective }\end{array}$ & 13,25 & $\begin{array}{c}\text { Very } \\
\text { objective }\end{array}$ & 13,50 & $\begin{array}{c}\text { Very } \\
\text { objective }\end{array}$ \\
\hline 5 & Practicality & 16,50 & Practical & 16,50 & Practical & 17,00 & Practical & 17,25 & Practical \\
\hline 6 & Language Use & 11,75 & Good & 12,25 & Good & 12,50 & Good & 12,50 & Good \\
\hline
\end{tabular}




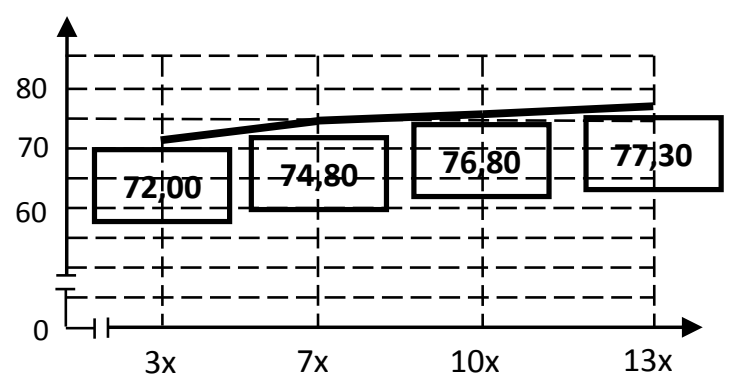

Figure 3. The Diagram of the Results of Integrated Learning Effectiveness Measurement from the Perspective of the Students

Tabel 3. The Results of Effectiveness Measurement on the Integrated Learning

\begin{tabular}{rlcccccc}
\hline \multirow{2}{*}{ No } & \multirow{2}{*}{ Aspects of Assessment } & \multicolumn{6}{c}{ Results of Assessment } \\
\cline { 3 - 8 } & & \multicolumn{2}{c}{ LP 1, LP 2 } & \multicolumn{2}{c}{ LP 3, LP 4 } & \multicolumn{2}{c}{ LP 5, LP 6, LP 7 } \\
\cline { 2 - 7 } & Mean & Criteria & Mean & Criteria & Mean & Criteria \\
\hline 1 & Overall & 144,00 & Good & 144,00 & Good & 150,00 & Very Good \\
2 & General implementation & 22,50 & Good & 23,00 & Good & 25,00 & Good \\
3 & Planning and objective & 19,00 & Good & 18,50 & Good & 19,50 & Very Good \\
4 & Interaction & 15,50 & Good & 17,00 & Good & 17,50 & Good \\
5 & Learning materials & 10,00 & Good & 10,00 & Good & 10,00 & Good \\
6 & Reading materials & 10,50 & Good & 10,00 & Good & 10,00 & Good \\
7 & Assignments & 9,00 & Good & 9,00 & Good & 9,50 & Good \\
8 & Assessment & 16,50 & Good & 16,00 & Good & 16,50 & Good \\
9 & Teachers & 29,00 & Good & 29,50 & Very Good & 30,00 & Very Good \\
10 & Language use & 12,00 & Good & 10,50 & Good & 11,50 & Good \\
\hline
\end{tabular}

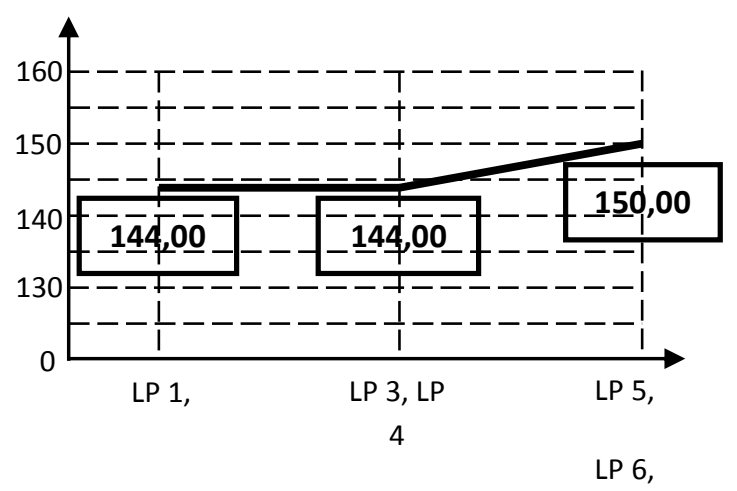

Figure 4. The Diagram of Implementation Measurement on the Integrated Learning

Based on the analysis on the effectiveness of integrated learning, both from the perspective of the teachers and of the students, the researchers concluded that in general the implementation of the integrated learning had been in the category of effective to very effective.
The researchers observed the implementation of integrated learning for three times namely: (1) at the end of the first and the second lesson plan (LP); (2) at the end of the third and the fourth lesson plan; and (3) at the end of the fifth and the sixth lesson plan. 
The analysis of integrated learning implementation was identical to that of the lesson plans within the teaching-learning process. The results of the analysis showed that the implementation of integrated learning had been under the criteria of good to very good.

The teachers' activities in the integrated learning were the ones involved in the teaching-learning process, that had been directed to the activities that had been mentioned in the already formulated indicators. The observers on the teachers' activities were four university students who had been assigned by the researchers. The observed the teachers' activities, both the productive ones and the entre- preneurial ones, within the teaching process. The proportion of the observers was divided as follows: two university students served as the observers for a productive teacher and the other two university students served as the observers for an entrepreneurial teacher. The data gathering was performed by means of an instrument of teacher activities measurement and was performed for four times namely: (1) at the end of the fourth meeting; (2) at the end of the eighth meeting; (3) at the end of the twelfth meeting; and (4) at the end of the sixteenth meeting. From the results of the analysis, the researcher would like to draw the following conclusion:

Tabel 4. The Results of Teacher Activities Measurement in the Integrated Learning

\begin{tabular}{|c|c|c|c|c|c|c|c|c|c|}
\hline \multirow{3}{*}{ No } & \multirow{3}{*}{$\begin{array}{c}\text { Aspects of } \\
\text { Measurement }\end{array}$} & \multicolumn{8}{|c|}{ Note } \\
\hline & & \multicolumn{2}{|c|}{$\begin{array}{l}\text { At the end of the } \\
4^{\text {th }} \text { meeting }\end{array}$} & \multicolumn{2}{|c|}{$\begin{array}{l}\text { At the end of the } \\
8^{\text {th }} \text { meeting }\end{array}$} & \multicolumn{2}{|c|}{$\begin{array}{l}\text { At the end of the } \\
12^{\text {th }} \text { meeting }\end{array}$} & \multicolumn{2}{|c|}{$\begin{array}{l}\text { At the end of the } \\
16^{\text {th }} \text { meeting }\end{array}$} \\
\hline & & Mean & Criteria & Mean & Criteria & Mean & Criteria & Mean & Criteria \\
\hline 1 & Overall & 86,80 & Active & 86,80 & Active & 89,50 & Active & 90,50 & Active \\
\hline 2 & Introduction & 17,30 & Active & 17,30 & Active & 18,30 & Active & 19,00 & Active \\
\hline 3 & Core activities & 46,00 & Active & 46,50 & Active & 46,80 & Active & 47,80 & Active \\
\hline 4 & Conclusion & 12,80 & Active & 12,00 & Active & 12,80 & Active & 13,00 & Very Active \\
\hline 5 & Language use & 10,80 & Active & 11,00 & Active & 11,80 & Active & 10,80 & Active \\
\hline
\end{tabular}

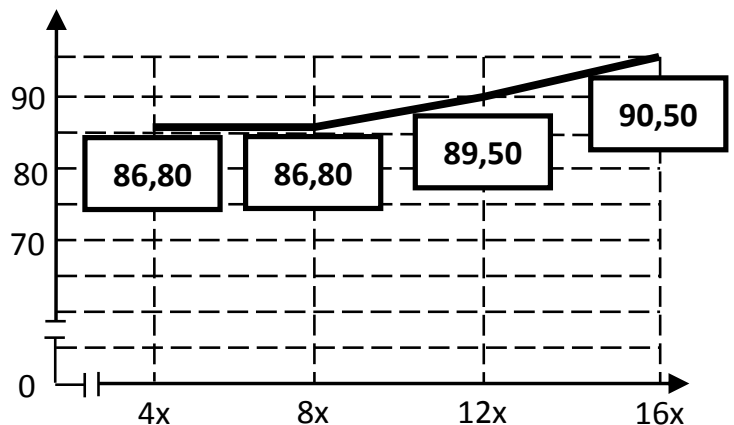

Figure 5. The Diagram of Measurement Results on the Teacher Activities in the Integrated Learning

The students' activities in the research were the ones in the implementation of integrated learning and these activities led to the ones that had been stated in the already formulated indicators. The observers of the students' activities were four university students that had been assigned by the research- ers. These university students observed the students' activities in attending the integrated learning process. Principally, the observation was focused on the class dynamic. One student served as an observer for a quarter of the students who attended the integrated learning process within the classroom. In this 
case, the quarter of the students were gathered into a working group with 4-5 members for each group. The data gathering was performed toward the students' activities around four times as follows: (1) the first data gathering was performed at the end of the fourth meeting; (2) the second data gathering was performed at the end of the eighth meeting; (3) the third data gathering was performed at the end of the twelfth meeting; and (4) the fourth data gathering was performed at the end of the sixteenth meeting.

Tabel 5. The Results of Students' Activities in the Integrated Learning

\begin{tabular}{|c|c|c|c|c|c|c|c|c|c|}
\hline \multirow{3}{*}{ No } & \multirow{3}{*}{$\begin{array}{c}\text { Aspects of } \\
\text { Measurement }\end{array}$} & \multicolumn{8}{|c|}{ Results of Measurement } \\
\hline & & \multicolumn{2}{|c|}{$\begin{array}{l}\text { At the end of the } \\
4^{\text {th }} \text { meeting }\end{array}$} & \multicolumn{2}{|c|}{$\begin{array}{l}\text { At the end of the } \\
8^{\text {th }} \text { meeting }\end{array}$} & \multicolumn{2}{|c|}{$\begin{array}{l}\text { At the end of the } \\
12^{\text {th }} \text { meeting }\end{array}$} & \multicolumn{2}{|c|}{$\begin{array}{l}\text { At the end of the } \\
16^{\text {th }} \text { meeting }\end{array}$} \\
\hline & & Mean & Criteria & Mean & Criteria & Mean & Criteria & Mean & Criteria \\
\hline 1 & Overall & 63,80 & Active & 65,30 & Active & 64,30 & Active & 64,50 & Active \\
\hline 2 & $\begin{array}{l}\text { Student concen- } \\
\text { tration during the } \\
\text { learning }\end{array}$ & 15,50 & Active & 15,50 & Active & 15,25 & Active & 16,00 & Active \\
\hline 3 & Taking notes & 12,25 & Active & 13,50 & Very Active & 12,75 & Active & 12,75 & Active \\
\hline 4 & Raising question & 12,00 & Active & 13,00 & Active & 12,75 & Very Active & 12,75 & Very Active \\
\hline 5 & $\begin{array}{l}\text { Answering } \\
\text { question }\end{array}$ & 9,00 & Active & 10,00 & Active & 10,00 & Active & 9,75 & Active \\
\hline 6 & Proposing opinion & 10,75 & Active & 9,75 & Active & 9,50 & Active & 9,75 & Active \\
\hline 7 & Language use & 13,00 & $\begin{array}{l}\text { Very } \\
\text { Active }\end{array}$ & 12,75 & Very Active & 12,50 & Very Active & 12,50 & Very Active \\
\hline
\end{tabular}

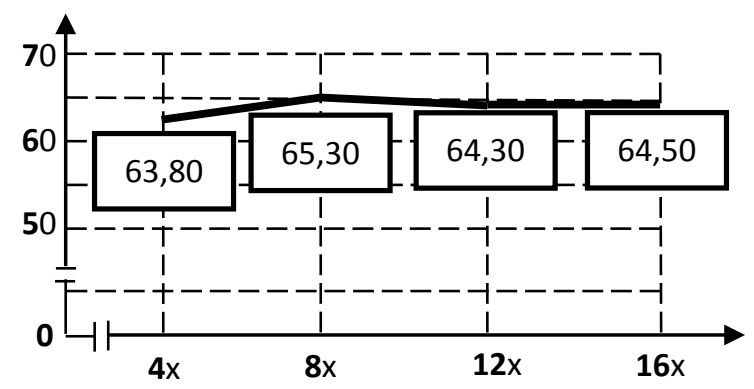

Figure 6. The Diagram of Measurement Results on the Students' Activities within the Integrated Learning

The entrepreneurial readiness referred to the students' performance or the students' readiness after they attended the integrated learning process. The integrated learning process might be measured from: (1) the performance in the aspects of practical knowledge; (2) the performance in the aspects of entrepreneurial knowledge; (3) the performance in the aspects of entrepreneurial attitudes; (4) the performance in the aspects of horizontal wall-plastering skills (individual); (5) the performance in the aspects of inner- angle horizontal wall-plastering skills (individual); (6) the performance in the aspects of outer-angle horizontal wall-plastering skills (individual); (7) the performance in the aspects of various wall-plastering skills; (8) the performance in the aspects of vertical ceramic-pairing skills on the vertical wall (individual); (9) the performance in the aspects of bath-tub and sink ceramic-pairing skills; and (10) the performance in the aspects of business proposal composition. The performance graphic would be described as follows: 


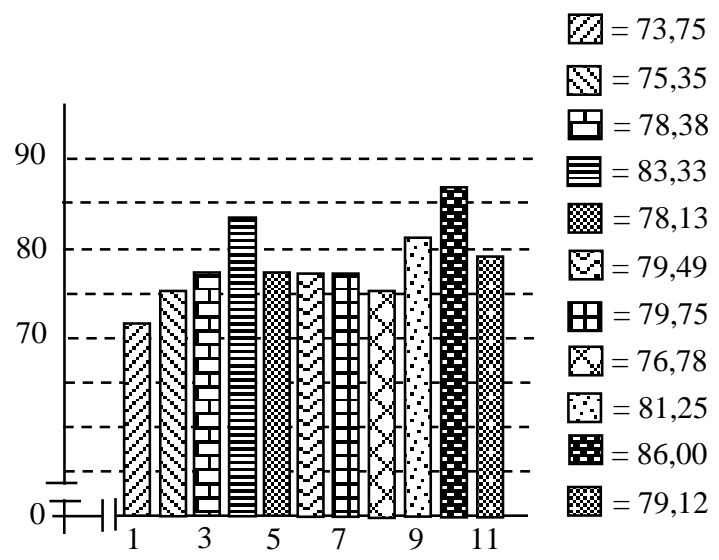

Figure 7. The Achievement Level of the Students' Entrepreneurial Readiness within the Integrated Learning

From the graphic, the histogram in number 11 showed was the average student performance that described the students' entrepreneurial readiness and the students' entrepreneurial readiness was measured based on the values in the histogram number 1 to the histogram number 10 . The students' entrepreneurial readiness in average was 79.12, which implied that after attending the integrated learning process the students were considered to be ready for performing the entrepreneurial efforts. The evidence was marked by the fact that the achievement of the learning results in overall exceeded the passing grade that had been stated $(\geq 70)$.

\section{CONCLUSIONS}

From the investigations that had been performed, the researchers would like to draw the following conclusions: (1) the implementation of integrated learning had been under the category of effective to very effective both from the perspective of the teachers and from the perspective of the students; (2) the implementation of integrated learning had been under the category of good to very good; (3) the teachers' and the students' activities in the implementation of integrated learning had been under the category of active to very active; and (4) the level of students' entrepreneurial readiness had been under the category of ready. For the further stage, the integrated learning might be implemented in the future learning process. similarly, the integrated learning might be generalized on the other subjects in order to achieve the characteristics of mutual synergy. Therefore, there should be a good cooperation from the related parties, such as the principal, the educators, the educational staffs and the elements of business domain, in order that they would be aware of the importance that the integrated learning possessed.

The suggestions that the researchers would like to propose were as follows: (1) the researchers would like to suggest that the involved parties such as the teachers, the principal and the practitioners would support the implementation of the integrated learning as an alternative program that might develop the students' entrepreneurial readiness; (2) the integrated learning had been in accordance with the integrated thematic learning since the integrated thematic learning was a form of learning process that deliberately associated several aspects of intra- or inter-subjects and, therefore, the integrated thematic learning should be focused on: (a) the learning participants as the core of the process; (b) the provision of direct experience to the learning participants; (c) the flexibility; (d) the hollisticness, meaning that the integrated thematic learning might be observed and be reviewed from several subjects altogether in the same time; (e) authenticity, meaning that the information and the knowledge that the learning participants attained had been actualized; and (f) activeness, meaning that the learning participants should be directly involved within the learning process starting from the planning, the implementation and the evaluation. 


\section{REFERENCES}

Borg, W. R., \& Gall, M. D. (1989). Educational research: an introduction (4th ed.). New York: Longman.

Drake, S. M. (2007). Creating standardsbased integrated curriculum: The common core state standards edition. California: Corwin Press a Sage Publishing Company.

Edward. (1982). Cara mengklasifikasikan kemampuan. Padang: FKT-IKIP Padang.

Finch, C. R., \& Crunkilton, J. R. (1999). Curriculum development in vocational and technical education: planning, content, and implementation (5th ed.). Boston: Allyn and Bacon.

Good, C. (1973). Dictionary of education. (M. G.-H. B. Company, Ed.). New York.

Hilgard, E. R., \& Bower, G. H. (1975). Theories of learning (4th ed.). New Jersey: Prentice-Hall.Inc.

Kaipa, P., \& Milus, T. (2005). Soft skills are smart skills. Retrieved from http://kaipagroup.com/articles/softskills. pdf

Kemendiknas. (2010). Pengembangan pendidikan kewirausahaan. Jakarta: Badan Penelitian dan pengembangan Pusat Kurikulum.

Khasali, R. (2010). Wirausaha mandiri, menggiat jiwa entrepreneur dari kampus. Retrieved November 19, 2010, from http://spirit-

bisnis.com/news/2010/06/wirausahamandiri-menggiat-jiwa-entrepreneurdari-kampus/105
Leung, L. (2008). How teached can broaden their soft skills. New York: IT Career and Training Alert Newsletter.

Mappa, S., Achsin, A., \& La Sulo, S. L. (1984). Teori belajar mengajar. Jakarta: Direktorat Jenderal Pendidikan Tnggi.

Matthoriq, Triwastuti, R., \& Hidayah, N. (2009). Konsep kaize sebagai basis pendidikan kewirausahaan di AMK dalam upaya mengurangi pengangguran di Jawa Timur. Journal, Research Study Club (RSC) FIA UB, 55(2).

Murtini, W. (2009). Kewirausahaan pendekatan succes story. Surakarta: Sebelas Maret University Press.

Presiden Republik Indonesia. Instruksi Presiden Republik Indonesia Nomor 4 Tahun 1995 tentang Gerakan Nasional Memasyarakatkan dan Membudayakan Kewirausahaan (1995).

Princes, H. (2004). Kewirausahaan dan motivasi. Yogyakarta: Darulsalam.

Santoso, P. B. (2009). Urgensi pendidikan kewirausahaan. Retrieved May 6, 2009, from http://www.wawasandigital.com

Soemanto, W. (2003). Psikologi pendidikan (landasan kerja pemimpin pendidikan). Jakarta: PT. Rineka Cipta.

Suryana. (2006). Kewirausahaan pedoman praktis: kiat dan proses menuju sukses (3rd ed.). Jakarta: Salemba Empat.

Zimmerer, T. W., \& Scarborough, N. M. (2008). Essentials of entrepreneurship and small business management (5th ed.). New Jersey: Pearson/Prentice Hall. 